\title{
INTEREST-RATE CHANGES AND THE VALUE OF A NON-LIFE INSURANCE COMPANY
}

\author{
BY
}

\author{
Thomas Albrecht, Allianz AG
}

\begin{abstract}
How does a change in the risk-free interest-rate affect the value of a non-life insurance company or portfolio? Risk managers typically argue that there should be little impact as long as assets and liabilities are properly matched. However, the risk-management perspective focuses on existing assets and liabilities, while neglecting the value of future business potential. This paper argues that interest-rate changes can have a significant impact on the appraisal value of a non-life insurance company, even if assets and liabilities are matched. This impact can be positive as well as negative, depending on the underlying parameters. Relevant parameters include reserving intensity, combined ratio, business growth-rate, asset allocation, risk-capital relative to premium income and the correlation between interest-rate and technical insurance results.
\end{abstract}

\section{KEYWORDS}

Valuation, Interest-Rates, Asset-Liability-Management

\section{Interest-Rate Changes And the Value of A Non-LifE INSURANCE COMPANY}

What impact does a change in the risk-free interest-rate have on the present value of a non-life insurance company or portfolio?

The topic of interest-rate changes has received substantial attention in the case of life-insurance companies (see, among others, BABBEL (1995), HoLSBOER (2000), Dickinson (2000) and SigLIENTI (2000)), as in several countries the industry has had to cope with very low market interest-rates, while long-term contracts with guaranteed minimum returns had to be honored.

For non-life companies, the issue has been discussed less extensively. Several authors have analyzed proper asset-liability-management in the face of interest-rate risks. However, their work tends to focus on existing assets and liabilities (e.g. D'Arcy / Gorvett (2000) and CAmpbell (1997)), while 
neglecting the impact of interest-rate changes on the value of future business potential. Such an approach is appropriate for short-term risk-management purposes (i.e. safeguarding the required solvency-capital at any given point in time) as well as for evaluating a pure run-off portfolio. To assess the interest sensitivity of a going-concern appraisal value (or market value), an extended framework is needed. So far, attempts in this direction have been made in the context of dynamic financial analysis ${ }^{1}$, and in a paper by PANNING (1995). However, PANNING - among other simplifications - only analyses the case of a break-even combined ratio and uses discount-rates without risk-adjustment ${ }^{2}$. This paper tries to provide a more extended treatment of the issues involved.

\section{Basic DCF-Valuation of a Non-Life Insurance Company}

The available literature on non-life insurance DCF-valuation is comparatively small. A discussion of methodology and relevant problems can be found in Albrecht (2001), Copeland / Koller / Murrin (2000) and Hartung (2000).

The profit and loss account of a non-life insurer can - for example - be summarized in the following way:

\begin{tabular}{ll}
\hline \hline $\begin{array}{l}\text { Earned net premiums } \\
-\end{array}$ & losses incurred \\
- & administration and acquisition expenses \\
\hline$=$ & technical result \\
+ & investment income on insurance reserves \\
+ & investment income on equity \\
$+/-$ & other íncome / expense \\
\hline$=$ & profit before tax \\
$+/-$ & taxes \\
\hline$=$ & profit after tax \\
- & retained profit \\
\hline$=$ & dividend \\
\hline \hline
\end{tabular}

1 Dynamic financial analysis subjects financial models to scenario testing or stochastic simulation to assess the impact of future events on the financial position of a company. For an overview, see D'Arcy / Gorvett / Herbers / Hettinger (1997) or Casualty Actuarial Society (1999).

2 Another paper dealing with market values, STAKING / BABBEL (1995), empirically examines the effect of asset duration (a proxy for interest-risk exposure) on the market-value of non-life insurers (more specifically, on Tobin's q). However, no attempt is made to discuss the effect of interest-rate changes on company value. Instead, the paper only deals with the connection between interest exposure and valuation premiums. 
To calculate the company value using a flow-to-equity approach, the future (potential) dividends are discounted at an adequate discount-rate.

If we use the simplifying assumption that dividends grow at a constant annual rate $g$ (this will typically not hold in real-life situations, but does not restrict the general analysis conducted in this article), yearly dividends can be written as follows:

\begin{tabular}{lcccc}
\hline \hline year & 1 & 2 & 3 & 4 \\
\hline dividend & $a$ & $a(1+g)$ & $a(1+g)^{2}$ & $a(1+g)^{3}$ \\
present value & $a /(1+d)$ & $a(1+g) /(1+d)^{2}$ & $\left.a(1+g)^{2} /(1+d)\right)^{3}$ & $a(1+g)^{3} /(1+d)^{4}$ \\
\hline \hline
\end{tabular}

As a perpetuity, the present value of this dividend stream can be written as: $a /(d-g)$

notation: $a$ expected amount of next dividend payment

$g$ growth-rate

$d$ discount-rate

Assuming that profit retention is determined by the company's growth (the required risk-capital will typically increase roughly proportional to premium income), company value $V$ can be written as (in $\%$ of mark-to-market equity):

$$
V=((r+i x+\operatorname{tr} n p)(1-t)-g) /(i+p r-g)
$$

with: $\quad a=(r+i x+\operatorname{tr} n p)(1-t)-g$

$=$ profit after tax and after growth-related profit-retention

$\mathrm{d}=i+p r$

$=$ risk-free interest-rate + adequate risk-premium

notation: $i$ risk-free interest-rate

$r$ expected investment return on shareholders' funds ${ }^{3}$, with $r=i+z>=i$

$z \quad$ risk-premium earned on investments (i.e. expected return in excess of risk-free rate)

$x$ insurance reserves in $\%$ of equity

tr technical result in $\%$ of net premiums $(t r=1-$ combined ratio; combined ratio $=c r)$

$n p \quad$ net premiums in $\%$ of equity

3 It is assumed that reserves are invested at the risk-free rate, whereas any risky investments are financed through the company's equity. All returns should be 'normalized', i.e. reflect expected average future earnings including expected (unrealized) capital gains. 


\section{$t$ tax-rate \\ pr risk-premium as part of discount-rate}

Some comments on plausible real-life parameters:

- $i$ is defined as constant for all maturities. This is obviously not compatible with reality and is only assumed to simplify the model. DRUKARCZYK (1998), p. 330ff., describes how to model interest-rates in more detail.

- $p r$ should be equal to the market risk-premium, if the company's investment and insurance risks imply a beta of roughly one. However, depending on the specific company - and especially on the investment policies followed -, beta may be considerably higher or lower than one ${ }^{4}$. Annual equity market risk-premiums are typically assumed in the range of $4-6$ percentage points, though views on adequate risk-premiums differ widely ${ }^{5}$.

- The assumed long-term growth-rate should be lower than the long-term interest-rate, if the empirical patterns of the past do not fundamentally change in the future (the nominal growth-rate of developed economies is typically lower than the nominal interest-rate). This obviously does not rule out higher growth-rates for the short- and mid-term in specific cases (or even the insurance industry as a whole).

- The risk-premium $z$ earned on investments financed by shareholders' funds should not exceed the risk-premium pr used in the cost-of-capital: The risk-level of the company assumed by choosing pr would already be fully made up of investment risk, if value = equity and $z=p r$ (Implicitly, it is assumed that the company earns risk-equivalent returns on investments and does not have the ability to earn excess-return through superior investment skills. If this were not the case, $\mathrm{z}$ might not be purely a risk-premium, but could also include excess returns earned). If value $>>$ equity, then $z>p r$ is in principle possible. However, since the technical insurance business should also be risky, and therefore required to earn a risk-premium, the assumption $z<p r$ seems sensible. For more details on the decomposition of systematic risk in investment and insurance-risk, see ALBRECHT (2001).

- A long-tail line of business with high insurance reserves $x$ will likely imply comparatively high combined ratios, as there will be more financial investments and therefore a better financial result to subsidise the technical insurance losses (e.g. SwISS RE (2001)).

- A higher proportion of equity relative to net premiums will typically be necessary for long-tail businesses with high amounts of reserving. Alternatively, for a given line-of-business, a high proportion of equity should imply

4 The risk of the company to be valued may depend on the choice of parameters: This paper assumes that an interest-rate change does not affect the risk-premium. However, this may be incorrect, as an interest-rate increase leads to higher risk-free payments on investments, thus potentially affecting the riskiness of the total cash-flow stream.

5 Albrecht (1999b), chapter 2, discusses the existing evidence on equity market risk-premiums. 
a low risk-premium $p r$, as the risk per unit of capital will be lowered, if the amount of capital is increased.

All other things being equal, an increase in the technical result (a decrease in the combined ratio) obviously increases company value $V$. Higher claims reserves (a longer duration of the run-off) also imply an increase in $V$, as they positively impact investment earnings. A higher risk-premium, on the other hand, negatively impacts $V$.

Not immediately clear is the effect of a higher growth-rate (lower discounting, but also higher profit retention), the net-effect hinges on the profitability of growth (i.e. if profit retention leads to sufficient future profits to earn cost-of-capital for the retained capital) ${ }^{6}$.

Also not immediately clear is the effect of a higher interest-rate. This effect is the main topic of this paper.

\section{Effects of Interest-Rate Changes on Company Value}

The asset-liability-management literature - e.g. D'ARCY / GORVETT (2000) and CAMPBELL (1997) - typically compares the interest-sensitivity of existing assets and liabilities: If both sides of the balance-sheet react to interest-rate changes in exactly the same way, the residual value of balance-sheet equity is not affected.

This approach is different from looking at the present value of future cashflows: Conceptually, the present value can be disaggregated into three components:

(1) The present value of future investment income and maturity refunds on existing assets.

(2) The present value of future claims payments on existing business.

(3) The present value of net payments from future insurance business.

Asset-liability management typically looks at (1) and (2), while neglecting (3). In contrast, the DCF-valuation formula for the appraisal value incorporates (1), (2) and (3).

In the context of this paper, the effect of interest-rate changes on the full appraisal value (fundamental market-value) of an insurance company is examined. Conceptually, this is similar to the work of PANNING (1995) and the field of dynamic financial analysis.

We can calculate the partial derivative of DCF-company value with respect to $i$ to derive the value impact of a change in i. In doing so, we can either assume that only $i$ alone changes, or that there are correlations with other variables (e.g. inflation, insurance-rates, share prices).

\footnotetext{
${ }^{6} d V / d g=(-(i+p r-g)+(r+i * x+t r * n p)(1-t)-g) /(i+p r-g)^{2}$

$>0$ for $(r+i * x+t r * n p)(1-t)>i+p r$

i.e. for return on equity $>$ discount-rate
} 
At first it is assumed that all investments are short-term (or at variable interest-rates). Subsequently, adjustments are made for the case of asset-liability-matching or other longer-term investment strategies.

\subsection{Pure Changes in the Real Interest-Rate with All Other Parameters Unchanged}

Let us assume that an interest-rate change does not affect any other parameter. Then, the partial derivative of company value $V$ with respect to $i$ is:

$$
\begin{aligned}
d V / d i= & \left(\left((1+x)(i+p r-g)-\left((i+z)+i^{*} x+t r * n p\right)\right)(1-t)+g\right) /(i+p r-g)^{2} \\
& >0 \text { for }((1+x)(p r-g)-\operatorname{tr} n p-z)(1-t)+g)>0
\end{aligned}
$$

(Note that $r=i+z$. The derivation assumes that the technical result is unaffected by interest-rate changes, $d \operatorname{tr} / d i=0$. Empirical evidence on this assumption is given in section 2.3. Also, it is assumed that accounting is based on undiscounted reserves. In the case of reserve-discounting, an increase in $\mathrm{i}$ decreases today's reserves, improving today's technical result. However, the discount unwinds in the future, leaving no overall net effect, apart from potential taxation issues.)

All other things being equal, it therefore follows that:

- The higher the cost-of-capital risk-premium pr and/or the combined ratio cr and/or the tax-rate $t$, the more likely will a higher interest-rate increase company value $V$.

- The higher the insurance reserves $x$, the more likely will a higher interestrate increase $V$ for $p r>g$, and decrease $V$ for $p r<g$.

- The higher the growth-rate $g$ and/or the investment risk-premium $z$, the more likely will a higher interest-rate decrease $V^{7}$.

- The higher premium income relative to equity, the more likely will a higher interest-rate increase $V$ for $\mathrm{cr}>100 \%$, and decrease $V$ for $\mathrm{cr}<100 \%$.

How can these effects be explained economically?

- The combined ratio ( $\mathrm{cr}$ ) is (by assumption) unrelated to interest-rates. According to the derivation above, an increase in the interest-rate implies a change in company value of $-\operatorname{tr} n p(1-t)=(c r-1) n p(1-t)$. For combined ratios above $100 \%$, the change in $\mathrm{V}$ is positive (the technical result taken on its own contributes a negative present value, which is reduced by higher interest-rates), for lower combined ratios it is negative (the present value of positive technical results is also reduced by higher interest-rates). In general, the higher the combined ratio, the higher the increase in $V$ (or the lower the decline in $V$ ) in case of an interest-rate increase.

\footnotetext{
7 In the case of $g$, the effect may be reversed if $x$ is very small and/or $t$ very high.
} 
- A higher cost-of-capital risk-premium ( $p r$ makes value increases in case of higher interest-rates more likely, as it softens the relative increase of the discount rate (with increasing pr, a given absolute change in i implies a smaller percentage change in $d=i+p r-g$ ).

- A higher investment risk-premium $(z)$ has the opposite effect: It lowers the relative increase in investment yield on shareholders' funds when interest-rates go up, as a given change in $i$ implies a smaller percentage change in $r=i+z$. However, as long as $d>r$, the present value of the future return on shareholders' funds still goes up with increases in $i$ (as the relative increase in the discount rate is still smaller than the relative increase in the investment yield).

- Future investment income is leveraged by the amount of insurance reserves ( $x)$. If the growth-adjusted discount-rate $(d=i+p r-g)$ is higher than the interest earned on investments (i.e. $p r>g$ ), higher interest-rates increase the present value of future investment income. This happens because an increase in $i$ has a smaller absolute effect on the discount-rate than on investment yield.

- The effects of the growth-rate $(g)$ are hardest to discuss. On one hand, growth-related profit retention reduces distributable profits. An increase in $i$ lowers the (negative) present value impact of not being able to distribute those profits. On the other hand, higher growth increases future profits. Insofar as those future profits are not interest-sensitive, an increase in $i$ lowers their present value. If the company is profitable (i.e. return on equity $>$ cost of capital), the value of future profits will be higher than the value of required profit retention, thus implying a negative overall effect of higher growth in case of an interest increase. If a company is unprofitable (i.e. technical result and investment returns are insufficient to finance the profit-retention required for long-term growth), the effect can go into reverse. However, as future investment returns are interest-sensitive, their present value does not decrease with an interest-rate increase. Thus, higher growth-rates negatively impact value sensitivity when interest rates go up, even if a company is unprofitable, except if insurance reserves are very small.

Table 1 shows some parameter constellations that can typically be observed in real-life situations (the table assumes a tax-rate of $35 \%$ ).

As can be seen, for combined ratios above $100 \%$ an interest-rate increase only implies a drop in value in the case of high growth rates. For combined ratios considerably below $100 \%$, however, an interest-rate increase is valuereducing under many realistic sets of parameters: If a company e.g. operates with a combined ratio of $95 \%$, an interest-rate increase would always be valuereducing, except if the company exhibits high insurance reserves as well as low growth-rates.

The extent of the change in value is especially high, if interest-rates and growth-rates are low: If growth is around zero and the interest-rate is $3 \%$, an interest-rate change of only one percentage point changes the value by $10-20 \%$. At $\mathrm{g}=0$ and $\mathrm{i}=2 \%$, di $=0.01$ even implies value changes of up to $30 \%$. 
TABLE 1

VALUE-IMPACT OF INTEREST-RATE CHANGES USING DIFFERENT SETS OF PARAMETERS

\begin{tabular}{|c|c|c|c|c|c|c|}
\hline \multicolumn{5}{|c|}{ assumed parameters } & \multirow{2}{*}{$\begin{array}{l}\text { increase in interest-rate } \\
\text { implies value-increase if }\end{array}$} & \multirow{2}{*}{$\begin{array}{c}\text { value-change at } \\
d i=1 \%, c r=10 \%^{8}\end{array}$} \\
\hline$p r$ & $g$ & $1 / n p$ & $x$ & $z$ & & \\
\hline $4 \% / 6 \%$ & $\mathbf{0} \%$ & $\mathbf{2 5} \%$ & 1 & $0 \%$ & $c r>98.0 \% / 97.5 \%$ & $16.7 \% / 20.0 \%$ \\
\hline $4 \% / 6 \%$ & $0 \%$ & $25 \%$ & 1 & $3 \%$ & $c r>98.8 \% / 98.3 \%$ & $6.9 \% / 10.0 \%$ \\
\hline $4 \% / 6 \%$ & $0 \%$ & $25 \%$ & 2 & $3 \%$ & $c r>97.8 \% / 96.3 \%$ & $9.4 \% / 12.5 \%$ \\
\hline $4 \% / 6 \%$ & $0 \%$ & $25 \%$ & 4 & $0 \%$ & $c r>95.0 \% / 92.5 \%$ & $16.7 \% / 20.0 \%$ \\
\hline $4 \% / 6 \%$ & $0 \%$ & $25 \%$ & 4 & $3 \%$ & $c r>95.8 \% / 93.3 \%$ & $11.8 \% / 15.0 \%$ \\
\hline $4 \% / 6 \%$ & $5 \%$ & $25 \%$ & 1 & $3 \%$ & $c r>99.4 \% / 98.4 \%$ & $3.0 \% / 5.9 \%$ \\
\hline $4 \% / 6 \%$ & $5 \%$ & $25 \%$ & 2 & $3 \%$ & $c r>99.6 \% / 98.1 \%$ & $1.1 \% / 4.0 \%$ \\
\hline $4 \% / 6 \%$ & $5 \%$ & $25 \%$ & 4 & $3 \%$ & $c r>100.1 \% / 97.5 \%$ & $-0.1 \% / 2.8 \%$ \\
\hline $4 \% / 6 \%$ & $10 \%$ & $25 \%$ & 1 & $0 \%$ & $c r>99.2 \% / 98.2 \%$ & $4.0 \% / 7.0 \%$ \\
\hline $4 \% / 6 \%$ & $10 \%$ & $25 \%$ & 1 & $3 \%$ & $c r>100.0 \% / 99.0 \%$ & $0.4 \% / 3.2 \%$ \\
\hline $4 \% / 6 \%$ & $10 \%$ & $25 \%$ & 2 & $3 \%$ & $c r>101.5 \% / 100.0 \%$ & $-2.6 \% / 0.1 \%$ \\
\hline $4 \% / 6 \%$ & $10 \%$ & $25 \%$ & 4 & $0 \%$ & $c r>103.7 \% / 101.2 \%$ & $-3.7 \% / 0.9 \%$ \\
\hline $4 \% / 6 \%$ & $10 \%$ & $25 \%$ & 4 & $3 \%$ & $c r>104.5 \% / 102.0 \%$ & $-4.2 \% /-1.5 \%$ \\
\hline $4 \% / 6 \%$ & $0 \%$ & $50 \%$ & 1 & $0 \%$ & $c r>96.0 \% / 94.0 \%$ & $16.7 \% / 20.0 \%$ \\
\hline $4 \% / 6 \%$ & $0 \%$ & $50 \%$ & 1 & $3 \%$ & $c r>97.5 \% / 95.5 \%$ & $6.9 \% / 10.0 \%$ \\
\hline $4 \% / 6 \%$ & $0 \%$ & $50 \%$ & 4 & $0 \%$ & $c r>90.0 \% / 85.0 \%$ & $16.7 \% / 20.0 \%$ \\
\hline $4 \% / 6 \%$ & $0 \%$ & $50 \%$ & 4 & $3 \%$ & $c r>91.5 \% / 86.5 \%$ & $11.8 \% / 15.0 \%$ \\
\hline $4 \% / 6 \%$ & $5 \%$ & $50 \%$ & 1 & $3 \%$ & $c r>98.7 \% / 95.2 \%$ & $3.0 \% / 5.9 \%$ \\
\hline $4 \% / 6 \%$ & $5 \%$ & $50 \%$ & 4 & $3 \%$ & $c r>100.2 \% / 95.2 \%$ & $-0.1 \% / 2.8 \%$ \\
\hline $4 \% / 6 \%$ & $10 \%$ & $50 \%$ & 1 & $0 \%$ & $c r>98.3 \% / 96.3 \%$ & $4.0 \% / 7.0 \%$ \\
\hline $4 \% / 6 \%$ & $10 \%$ & $50 \%$ & 1 & $3 \%$ & $c r>99.8 \% / 97.8 \%$ & $0.4 \% / 3.2 \%$ \\
\hline $4 \% / 6 \%$ & $10 \%$ & $50 \%$ & 4 & $0 \%$ & $c r>107.3 \% / 102.3 \%$ & $-3.7 \% / 0.9 \%$ \\
\hline $4 \% / 6 \%$ & $10 \%$ & $50 \%$ & 4 & $3 \%$ & $c r>108.8 \% / 103.8 \%$ & $-4.2 \% /-1.5 \%$ \\
\hline
\end{tabular}

\subsection{Inflation-Induced Interest-Rate Changes}

D'ARCY / GORVETT (2000) examine the impact of inflation on asset-liability management strategies for a run-off portfolio. They conclude that the "effective duration" of liabilities is lower, if interest-rate changes are correlated with changes in inflation. Put differently: If you have liabilities with a duration of $x$ years, locking-in an equivalent asset-duration of $x$ years only leads to proper asset-liability-matching, if the liability payments are not subject to changing

8 Interest-rates assumed: $3 \%(g=0), 8 \%(g=5 \%), 13 \%(g=10 \%)$. The higher the assumed interestrate, the lower the effect of an interest-rate change on company value. 
inflation-rates. If the liabilities are subject to changing inflation, the asset duration has to be shortened, so that the investment income received will also be subject to changes in inflation through the link between inflation and interestrates.

The same logic will now be applied to the DCF-valuation formula.

In case of purely inflation-induced interest-rate changes, $d g / d i=1$ follows, if premiums and profit also grow at the rate of inflation. In this case we can write:

$$
\begin{aligned}
d V / d & =((1+x)(1-t)-1)(i+p r-g) /(i+p r-g)^{2}=(x(1-\mathrm{t})-\mathrm{t}) /(i+p r-\mathrm{g}) \\
& >0 \quad \text { for } \quad x(1-t)>t \text { and } i+p r>g \\
& \text { for } \quad \text { (e.g.) } x>=1 \text { and } t<0,5 \text { and } i+p r>g
\end{aligned}
$$

An increase in inflation with other parameters unchanged seems to have a positive effect on company value, if the - not very restrictive - assumptions $x>=1, t<0.5$ hold.

However, this derivation is incomplete and therefore incorrect: The deduced value increase results from higher nominal interest income on the investments that are funded by insurance reserves. But a higher rate of inflation also implies a nominal increase in future claims payments, leading to a worsening technical run-off result. In other words, the implicit assumption of $d(\operatorname{tr} n p) / d i=0$ is no longer adequate. If claims inflation equals the general inflation rate, an inflation-induced interest-rate increase will not affect company value, as the technical result of subsequent calendar years will worsen when inflated claims are settled, exactly offsetting the higher nominal interest income. This becomes immediately apparent in a balance-sheet with discounted claims reserves: If the real interest-rate goes up, insurance reserves are discounted at a higher rate, implying a lower present value. If nominal interest-rate and inflation go up by the same amount, discount-rate and future nominal claims payments increase at the same rate, leaving the discounted reserves unchanged. In subsequent years, even though the higher nominal rate implies higher investment yields, reserves are also being inflated more quickly, with both effects offsetting each other.

For valuation purposes this implies that an increase in inflation has to be reflected not only in nominal interest-rate and growth, but also in the run-off result. In countries with high rates of inflation it may therefore be easier to use real instead of nominal figures.

However, a real approach neglects the potential negative tax effect of an inflation increase: For $t=0$, the higher interest earned on shareholders' funds is exactly sufficient to finance the necessary growth in nominal equity, as $d g=d i$. For $\mathrm{t}>0$, interest on shareholders' funds goes up only by $(1-\mathrm{t}) d i$, insufficient to fund growth of $d g=d i$. In this case, company value goes down if inflation goes up. However, the effect depends on the exact tax regime in place (this paper assumes a corporate tax rate and an additional income tax-rate which is applied to dividends as well as fixed income investments. While this is a reasonable assumption in many countries, it clearly does not apply in all cases. Under new German tax-rules, for example, income tax on dividends is 
lower than on fixed income, with potential implications for the after-tax costof-capital calculation).

\subsection{Correlation Between Interest-Rate Changes and Insurance Profit}

So far it was assumed that interest-rate changes do not affect other parameters: Neither did we assume a correlation with equity returns on the investment side, nor a correlation with the technical insurance result.

It is frequently argued that an increase in interest-rates has a negative effect on share prices, as future cash-flows are discounted more steeply ${ }^{9}$. Strictly speaking this only holds for changes in the real interest-rate (not for purely inflation-induced interest-rate changes), and only if an increase in the real interest-rate is not correlated with an increase in the future real profit potential. As argued in Albrecht (1999a, p. 127ff.), there is (ambiguous) evidence for such a correlation, so the relationship is less clear than it may seem at first glance.

However, a rough look at empirical data seems to validate the negative correlation between (nominal) interest-rates and share-prices: For the years 1981-99, the correlation between yearly returns of the German DAX and the German money market yield was -0.31 . The change in the money market yield was also negatively correlated with the DAX-return, at $-0.21^{10}$.

The technical result may also be correlated with the interest-rate: If industry participants think that higher interest-rates imply an improvement in the financial result, they might be tempted to increase the competitive pressure on rates (PANNING (1995), Dickinson (2000)). In this case, an interest-rate increase should be correlated with a worsening technical result (a higher loss ratio).

The yearly loss ratios of German non-life insurers for the years 1966-9911 are positively correlated with the money-market yield $(+0.30)$. Using first differences (i.e. changes in the interest-rate correlated with changes in the loss ratios), the positive correlation persists (not lagged: +0.18 ; lagged one year: $+0.24)$.

The correlation differs considerably between lines of business, however: While (e.g.) fire and transport had high positive correlations $(+0.54$ and $+0.38)$, liability and accident showed negative correlations ( -0.49 and -.45$)$.

Within the scope of this article, a detailed quantification of correlation effects shall not be attempted. For example, some of the correlations listed above might simply be spurious. However, it should be clear from the rough

\footnotetext{
9 See e.g. D'Arcy / GorvetT (2000), p. 396.

${ }^{10}$ DAX-return taken from GDV, table 100. Money-market yield from Albrecht (1999a), app. A 2.1. Similarly, AlbreCht (1998), p. 263, reports a positive correlation between DAX and REX in the period 1988-96. As REX is a fixed-income performance-index, higher interest-rates imply lower index-values. Consequently, a positive correlation between DAX and REX indicates a negative correlation between DAX and the general level of interest-rates.

${ }^{11}$ Source: GDV (several tables). Money-market yield from Albrecht (1999a), app. A 2.1.
} 
calculations performed above that correlations may have a major impact and merit further study.

\subsection{Effect of Asset Liability Matching and Other Investment Strategies}

If fixed-income investments are chosen to mature according to the expected timing of claims payments, the average term to maturity of the portfolio will depend on the ratio of reserves to premium income. If the payment structure is constant over time and the portfolio does not grow, claims reserves equaling yearly claims imply a medium payment period of 6 months. In the case of unearned premiums, the average payment period is also 6 months, if contracts are spread evenly over time with yearly renewal ${ }^{12}$.

The value-effect of such an investment strategy in the case of an interestrate change can be approximated via the change in present value of a fixed interest payment over the average payment period. The present value of fixedincome investments (excluding reinvestment risk, i.e. assuming zero-bond investments) can be approximated as ${ }^{13}$ :

Present Value (in \% of company equity) $=x\left(1+i_{f}(1-t)\right)^{m} /(1+i+p r)^{m}$ with: $i_{f} \quad$ fixed interest-rate $m$ average duration of insurance reserves

Table 2 shows some examples for value changes (in $\%$ of equity) $)^{14}$.

TABLE 2

CHANGE IN INTEREST-SENSITIVITY WHEN INVESTMENTS ARE MATCHED WITH LIABILITIES

\begin{tabular}{|c|c|c|c|c|c|c|}
\hline \multirow{2}{*}{$\begin{array}{c}\text { claims reserves } \\
\% \text { of claims }\end{array}$} & \multirow{2}{*}{$\begin{array}{l}\text { claims } \\
\text { ratio }\end{array}$} & \multirow{2}{*}{$\begin{array}{l}\text { unearned pr. } \\
\% \text { of net pr. }\end{array}$} & \multirow{2}{*}{$\begin{array}{c}\text { equity } \\
\% \text { of net pr. }\end{array}$} & \multicolumn{2}{|c|}{$->$ equals } & \multirow{2}{*}{$\begin{array}{c}\text { value effect of } \\
\qquad d i=0,01\end{array}$} \\
\hline & & & & $x$ & $m$ & \\
\hline $40 \%$ & $50 \%$ & $50 \%$ & $25 \%$ & 2.8 & 0.41 & $-1.0 \%$ \\
\hline $100 \%$ & $50 \%$ & $50 \%$ & $25 \%$ & 4.0 & 0.50 & $-1.8 \%$ \\
\hline $100 \%$ & $50 \%$ & $50 \%$ & $50 \%$ & 2.0 & 0.50 & $-0.9 \%$ \\
\hline $200 \%$ & $50 \%$ & $50 \%$ & $50 \%$ & 3.0 & 0.83 & $-2.2 \%$ \\
\hline $300 \%$ & $50 \%$ & $50 \%$ & $50 \%$ & 4.0 & 1.25 & $-4.2 \%$ \\
\hline
\end{tabular}

12 Assuming a stagnant portfolio, 1/12 of unearned premiums will be earned in 12 months' time, 1/12 in 11 months, etc. On average, the unearned premiums on the balance-sheet at any point in time will therefore remain for 6 months. If the portfolio is growing, a larger part of unearned premiums will be earned in later months, implying a longer average duration than 6 months.

${ }^{13}$ Calculation excludes investments backed by shareholders' funds. It may be argued that the discountrate should not include the full risk-premium $p r$, as the fixed-income portfolio in itself is not subject to the full company risk. However, omitting $p r$ hardly affects the interest-sensitivities.

${ }^{14}$ For $i_{f}=i=0.05, p r=0.04$ und $t=0.35$. Changes in $p r$ and $t$ have no major effect on the result. 
As can be seen, asset-liability-matching results in rather short terms to maturities for broadly diversified p/c-insurers: Even if parts of a large insurance portfolio have a very long run-off period, an average period until maturity of more than a year $(m>1)$ should be the exception rather than the rule, as it would imply a ratio of claims reserves to claims considerably in excess of $200 \%$. As a consequence, an interest-rate increase has rather small effects on the present value of liability-matched asset portfolios for all but insurers with long tails (high values for $x$ and $m$ ).

To give an example, the non-life operations of German insurer Allianz AG show total (net) claims provisions of $45.3 \mathrm{~b}$ Euro in 2001 and net earned premiums of $34.4 b$ Euro. The ratio of claims reserves to premiums is $132 \%$ (Allianz (2002), p. 4 and p. 48), the average duration equals roughly 0.6 years (using the simplified assumptions of stable business volume and constant payment pattern).

For specialized long-tail insurers, the ratio can be much higher, though. One example for longer-tail business is MAT (Marine Aviation Transport). In its 2000 financial statements, AGF MAT (a subsidiary of Allianz AG) shows (net) claims provisions of $384 \mathrm{~m}$ Euro and net earned premiums of $132 \mathrm{~m}$ Euro. This equals a ratio of $291 \%$. As there are no unearned premiums at year-end (MAT-contracts typically start at the beginning of the calendar-year), the ratio implies an average duration of roughly 1.5 years (17.5 months).

Other business lines, e.g. workers' compensation or bonding, may exhibit much longer average durations, though they are rarely run as stand-alone companies.

Insurers frequently hold portfolios with durations far in excess of assetliability-matching. Table 3 shows the present value effects of an average of several years until maturity:

TABLE 3

CHANGE IN INTEREST-SENSITIVITY WHEN INVESTMENT MATURITIES ARE LENGHTENED

\begin{tabular}{ccccc}
\hline \hline & \multicolumn{4}{c}{ value effect of $\boldsymbol{d} \boldsymbol{i}=\mathbf{0 , 0 1}$ for time until maturity of } \\
$\boldsymbol{x}$ & $\mathbf{2}$ & $\mathbf{3}$ & $\mathbf{4}$ & $\mathbf{5}$ years \\
\hline 1 & $-1.6 \%$ & $-2.3 \%$ & $-2.9 \%$ & $-3.4 \%$ \\
2 & $-3.2 \%$ & $-4.6 \%$ & $-5.8 \%$ & $-6.8 \%$ \\
4 & $-6.5 \%$ & $-9.2 \%$ & $-11.6 \%$ & $-13.6 \%$ \\
\hline \hline
\end{tabular}

If reserves are high compared to equity (high values of $x$ ), a portfolio duration of several years quickly leads to a double-digit impact on the company's markto-market equity, even when interest-rates increase by only one percentage point. 


\section{Case-Studies on the Total Effect of Interest-Rate Changes}

As discussed, different sets of parameters will imply very different reactions of company value to interest-rate changes. This chapter intends to give examples of companies that are quite susceptible or less susceptible to interest-rate risk $^{15}$

Non-company-specific parameters used throughout are $i=0.05, p r=0.04$ and $t=0.35$.

Company $A$ is a retail insurer with a high franchise value (low combined ratio, high growth rate). Parameters are as follows: $\mathrm{cr}=0.95, \mathrm{~g}=0.05 x=4$, $n p=4, z=0$.

According to the DCF-valuation formula, A's appraisal value is 6.06 times equity. Assuming short-term investments, an interest-rate increase of $d i=0.01$ implies a new value of 5.50 times equity, i.e. a drop in value of $9 \%$.

If $\mathrm{A}$ had opted for a long-term investment strategy ( $m=5$ years), value would have dropped by a further 0.14 times equity, i.e. the total interest-related drop would have been $12 \%$. Compared to total company value, the effect of the investment strategy is small, as A's franchise value is far in excess of equity. Nevertheless, long-term investments increase A's sensitivity to interest-rate changes.

The effect occurs irrespective of tail: If $\mathrm{A}$ is assumed to have a much longer tail, interest-rate increases still imply a drop in value with short-term investment strategies, and a bigger drop with longer-term investments.

Company $B$ is considerably less profitable, but also boasts a high growthrate. Parameters are: $\mathrm{cr}=1.02, g=0.05, x=4, n p=4, z=0$.

$B$ 's appraisal value is 1.51 times equity. Assuming short-term investments, $d i=0.01$ implies a new value of 1.86 times equity, i.e. an increase in value of $23 \%$.

If $B$ had opted for a long-term investment strategy ( $m=5$ years), the negative value-impact would again have been 0.14 times equity. Total value after the interest-change would then be 1.72 times equity, an increase of $14 \%$ compared to the initial value.

For $B$, a long-term investment portfolio actually decreases the interestsensitivity of the company's appraisal value, even though $B$ is not a long-tail insurer. This happens because the future profits of the company are earned through investment income, while the technical result is negative. The higher investment income overcompensates the higher discount-rate for the parameters chosen.

$B$ has a second option to lower its interest-sensitivity: It can increase the portion of equity that is invested in risky assets (e.g. stocks): Assuming e.g. $z=0.03, d i=0.01$ only increases company value by $13 \%$ (short term

${ }^{15}$ Unless otherwise mentioned, only changes in the real rate are considered. 
investments) / $6 \%$ (long-term investments). This happens because the additional expected return $(z)$ is assumed to accrue irrespective of interest-rate increases. A higher interest-rate lowers the present value of the risk-premium earned, another counter-cyclical effect on $B$ 's value.

Company $C$ is a long-tail industrial insurer with low profitability (high combined ratio) and low growth perspectives. Parameters are: $\mathrm{cr}=1.1, \mathrm{~g}=0$, $x=8, n p=3, z=0$.

$C$ 's appraisal value is 1.08 times equity. Assuming short-term investments, $d i=0.01$ implies a new value of 1.56 times equity, i.e. an increase in value of $44 \%$.

For $C$, the higher investment earnings on the long tail more than overcompensate the lower present value of future profits (which is assumed to be low anyway). However, for such an insurer, the higher profitability caused by higher interest-earnings is likely to spark more aggressive competition on rates, thus increasing long-term combined ratios - an effect not covered by applying the formula on a ceteris paribus basis.

If $C$ had opted for a long-term investment strategy ( $m=5$ years), the negative value-impact would have been 0.27 times equity. Total value after the interest-change would then be 1.29 times equity, still a $19 \%$ increase compared to the initial value. Again, as with $\mathrm{B}$, long-term investments decrease the interest-sensitivity of $C$ 's value.

The examples discussed above illustrate the limitations of PANNING's (1995) analysis: PANNING argues that the duration of investments should generally be lengthened to counter-balance the interest-sensitivity of future business value ${ }^{16}$. In his analysis, future business value has a negative duration (i.e. the value increases when interest-rates go up), because the duration of future losses is higher than the duration of future premiums. However, this only holds under his non-general assumption of break-even premiums. For sufficiently profitable companies (like company $A$ ), the effect goes into reverse.

What would have happened to $A, B$ and $C$ in the case of inflation-induced interest-rate changes? Assuming that a change in inflation does not affect the underlying profitability of the insurance business ${ }^{17}$, and also neglecting potential tax-effects, the only effect of such an interest-rate change would be on the present value of longer-term fixed-income investments. The higher the inflationrisk, the higher the value sensitivity of longer-term investments. This serves to make longer-term investments less attractive, irrespective of company characteristics. Companies A, B and C should all lower their investment durations if inflation-uncertainty increases.

\footnotetext{
${ }^{16}$ Assuming - as is done here - that future premiums are fixed, i.e. not interest-sensitive.

17 The extensive literature on the effect of inflation on business profitability cannot be discussed here due to space constraints. However, it can be argued that the results are quite inconclusive.
} 


\section{EMPIRICAL RESUlTS FOR GERMANY}

It can be empirically verified if the market capitalisation of companies is correlated with interest-rate changes. However, changes in market capitalisation can only correctly reflect the fundamental effects of interest-rate changes, if market participants under-stand and correctly price those underlying fundamental effects. As this cannot be taken for granted - given the complexities of those effects - any empirical results should be interpreted with caution.

To capture the effect of interest-rate changes, unexpected changes should be used, as expected changes will already be anticipated in the share price. Consequently, the variable used to explain share-price effects cannot be the change in money-market rates, but only a performance-index for fixed-income securities.

To examine, if and to what extent the monthly stock-returns of major German companies between January 1990 and May 2001 can be explained by the REX-return (REX is a performance-index based on German fixed-income government securities of different maturities; regression is performed on the basis of Bloomberg-data), the following regression was performed (results shown in table 4):

$$
r_{\text {company, } \mathrm{i}}=a+b * r_{\text {rex }, i}+\varepsilon_{i}
$$

with: $\quad r_{\text {company, } i} \quad$ return of the company's stock in month $i$ $r_{\text {rex, } i} \quad$ return of the REX-index in month $i$

TABLE 4

EMPIRICAL INTEREST-SENSITIVITY OF GERMAN COMPANIES' MARKET CAPITALISATION

\begin{tabular}{|c|c|c|c|}
\hline company & coefficient & standard error & $R^{2}$ \\
\hline \multicolumn{4}{|l|}{ insurance } \\
\hline Allianz & 2,47 & $0,64 * *$ & 0,10 \\
\hline Munich Re & 2,17 & $0,78 * *$ & 0,05 \\
\hline \multicolumn{4}{|l|}{ banking } \\
\hline Commerzbank & 1,16 & 0,64 & 0,02 \\
\hline Deutsche Bank & 0,69 & 0,74 & 0,01 \\
\hline Dresdner Bank & 0,99 & 0,76 & 0,01 \\
\hline \multicolumn{4}{|c|}{ non-financial sector } \\
\hline BASF & 0,82 & 0,63 & 0,01 \\
\hline Bayer & 1,29 & $0,61^{*}$ & 0,03 \\
\hline SAP & $-2,10$ & 1,12 & 0,03 \\
\hline Siemens & 0,67 & 0,78 & 0,01 \\
\hline Volkswagen & 1,12 & 0,82 & 0,01 \\
\hline
\end{tabular}


With the exception of SAP, the coefficient of the REX-return is positive in all cases, i.e. an increase of REX (a decrease in the return of fixed-income securities) tends to imply an increase in share prices. However, for banks as well as non-financial companies, the standard error is nearly as high as the coefficient, and $\mathrm{R}^{2}$ is practically zero. The only exception are the two insurers Allianz and Munich Re: The standard error is low relative to the coefficient, and $\mathrm{R}^{2}$ implies an explanatory content of $5 \%$ and $10 \%$ of total share-price variance. This may sound low at first glance, but given the multitude of effects that influence shareprices, a higher explanatory content of interest-rate changes alone cannot plausibly be expected.

The result of this - rather rough and superficial - empirical analysis is that interest-rate changes do not in general have a strong effect on the market capitalisation of German companies. However, interest-rate increases do have a discernible (negative) impact on the market capitalisation of German insurance companies.

\section{So is this in line with the theoretical analysis?}

The financial statements of Allianz AG for the financial year 2000 show lendings and fixed-income securities of $189 b$ Euro, of which $91 b$ Euro with a remaining term to maturity of more than 5 years. Roughly $2 / 3$ of investments are linked to life/health-business, where the bulk of investment income is passed on to policyholders. Assuming proportional allocation, roughly $60 \mathrm{~b}$ Euro of total investments - of which $30 \mathrm{~b}$ Euro with a remaining term to maturity of more than 5 years - should directly affect company value. It therefore sounds plausible to assume an average term to maturity of 5 years for the $60 \mathrm{~b}$ Euro in total investments. If we compare this to the company's equity of $35 b$ Euro, the result is roughly $x=2$, implying a negative value effect of $-3.8 \%$ if interest-rates go up by one percentage point. At the same time, the base-effect of an interest-rate increase (as discussed in 2.1) should be close to zero in the case of Allianz AG, if we assume $p r=0.04, x=2, c r$ around 1.00 , and $g=0.05$ or less. Finally, the market may expect a negative correlation between interestrates and technical insurance-results. In total, the theoretical effect of an interestrate increase on the value of Allianz AG may therefore truly be negative, just like the empirical results indicate.

However, the empirical results can only be interpreted with great caution, as multi-national companies like Allianz and Munich Re will not only be affected by changes in German interest-rates, but by other countries' interest-rates as well. Furthermore, as those companies also write life and health-business, they might be subject to other effects which are not covered by this analysis.

\section{CONCLUSIONS}

Without a doubt the analytical model developed in this paper is simplified in several respects. To give just one example, it could be explicitly modelled that 
interest-rate changes are not identical over the whole yield-curve, but instead tend to be less pronounced for long maturities ${ }^{18}$.

Nevertheless, the analysis leads to some general conclusions. Specifically, it was shown that a change in the interest-rate can affect the value of a non-life insurance company positively as well as negatively, depending on the underlying parameters:

If the investments are predominantly long-term (more than would be the case for mere asset-liability-matching) and average combined ratios comparatively low, a value reduction in case of increasing interest-rates is likely. This effect seems to dominate for the German insurers Allianz and Munich Re.

However, there is no reason to generalize this result: Companies/portfolios with low expected growth-rates, combined ratios around or above $100 \%$ and/or a comparatively short-term investment portfolio will on the contrary experience an increase in fundamental DCF-value if the market interest-rate goes up.

The effects of an interest-rate change on company value can be summarized as follows:

- An increase in the real interest-rate can affect company value positively or negatively, depending on the underlying parameters. The different effects on company value are:

1. A lower present value of run-off claims ( $\rightarrow$ increases value).

2. A lower present value of existing fixed-income securities ( $\rightarrow$ lowers value).

3. A lower present value of technical profits earned from future insurance business (combined ratio $<100 \%$ ) or of deficits incurred (combined ratio $>100 \%)(\rightarrow$ increases or lowers value, depending on the combined ratio). In addition, if the combined ratio worsens because rising interest-rates increase the competitive pressure, this will negatively affect the present value.

4. A lower or higher present value of investment income in connection with future business (the lower the growth-rate of future business, and the higher the risk- premium in the discount-rate, the more likely will a higher interest-rate imply a higher present value of future investment income from future reserves).

- On the other hand, an increasing rate of inflation (with a corresponding rise in the nominal interest-rate) does not influence company value in a world without taxes - provided investments are short-term/variable rate - because higher interest-income will be compensated by higher nominal claims payments and a higher discount-rate for future profits (although it is possible that an increase in inflation may have consequences on real parameters and therefore company value). Longer-term fixed-income investments, however, imply a decrease in company value in case of an interest-rate increase, as claims inflation will not be compensated by higher investment returns until investments are reinvested after maturity. A further decrease in value results

18 This follows from the market participants' expectations of future interest-rate changes. See LevIN (1996), ANKER (1993) or AlBRECHT (1999a). The simple assumption of a parallel shift in the yield-curve, as used in this paper, implies an over-estimation of long-term effects in section 2.1 relative to section 2.4. 
from taxation effects under the tax regime assumed in this paper (though other tax regimes may have different effects).

\section{REFERENCES}

Albrecht, T. (2001) Discounted-Cash-Flow Bewertung bei Sachversicherungsunternehmen, Finanz Betrieb 5/2001, p. 302-307.

Albrecht, T. (1999a) Die Wahl der Zinsbindungsdauer, Hamburg.

Albrecht, T. (1999b) Asset Allocation und Zeithorizont, Bad Soden/Ts.

Albrecht, T. (1998) Die Vereinbarkeit der Value-at-Risk-Methode in Banken mit anteilseignerorientierter Unternehmensführung, Zeitschrift für Betriebswirtschaft 68, 259-273

AGF MAT (2001) Annual Report 2000.

Allianz Group (2001, 2002) Group Financial Statements 2000, 2001

Anker, P. (1992) Zinsstruktur und Zinsprognose, Giessen.

BABBEL, D.F. (1995) Asset-Liability Matching in the Life-Insurance Industry, The Financial Dynmics of the Insurance Industry, Altman and Vanderhoof (eds.), Chapter 11.

CAmpbell, F. (1997) Asset/Liability Management for Property/Casualty Insurers, The Handbook of Fixed Income Securities, Fabozzi (ed.), Chapter 51.

Casualty Actuarial Society (1999) Overview of Dynamic Financial Analysis, website of the Casualty Actuarial Society, www.casact.org/researchldfa.

Copeland, T., Koller, T. and Murrin, J. (2000) Valuation, 3rd Edition, New York (et al.)

D'Arcy, S. and GorvetT, R. (2000) Measuring the Interest Rate Sensitivity of Loss Reserves, Proceedings of the Casualty Actuarial Society, 87, 365-400.

D’Arcy, S., Gorvett, R., Herbers, J. and Hettinger, T. (1997) Building a DFA Analysis Model that Flies, Contingencies Magazine, Nov./Dec. 1997, reprinted on the website of the Casualty Actuarial Society, www.casact.org/coneduc/specsem/98dfaldfamodel.htm.

DRUKARCZYK, J. (1998) Unternehmensbewertung, 2nd Edition, München.

GDV (2001) Statistisches Taschenbuch der Versicherungswirtschaft 2000, download from www. gdv.de.

HARTUNG, T. (2000) Unternehmensbewertung von Versicherungsgesellschaften, Wiesbaden

Holsboer, J. H. (2000) The Impact of Low Interest Rates on Insurers, Geneva Papers on Risk and Insurance, 25, 38-58.

Levin, F. (1996) Die Erwartungstheorie der Zinsstruktur, Frankfurt/M.

PAnning, W.H. (1995) Asset-Liability Management for a Going Concern, The Financial Dynamics of the Insurance Industry, Altman and Vanderhoof (eds.), Chapter 12.

Siglienti, S. (2000) Consequences of the Reduction of Interest Rates on Insurance, Geneva Papers on Risk and Insurance, 25, 63-77.

Staking, K. and Babbel, D. (1995) The Relation Between Capital Structure, Interest Rate Sensitivity, and Market Value in the Property-Liability Insurance Industry, Journal of Risk and Insurance, 62, 690-718.

Swiss RE (2001) Rentabilität der Nichtleben-Versicherungswirtschaft: Zurück zum Underwriting, Sigma 5/2001, Zürich.

Dr. Thomas AlBRecht

Treffauerstr. 38

D-81373 München

thomas.albrecht@allianz.com

Tel. +498938007481

Fax +4989380019422 